\title{
Seasonal Incidence of Sucking Pest of Okra and its Relationship with Weather Parameters in Summer Season
}

\author{
S.R. Dhandge*, S.A. Bangale, A.S. Vaja and V.R. Virani \\ Department of Entomology, College of Agriculture, Junagadh Agricultural University, \\ Junagadh - 362001, India \\ *Corresponding author
}

\section{A B S T R A C T}

\section{Keywords \\ Okra, Bemisia tabaci, \\ Sesonal incidence, $A$. \\ biguttula biguttula and Junagadh \\ Article Info \\ Accepted: \\ 22 October 2018 \\ Available Online: \\ 10 November 2018}

Investigation on seasonal incidence of sucking pest of okra and its relationship with weather parameters was carried out at Instructional Farm, College of Agriculture, Junagadh Agricultural University, Junagadh, Gujarat during summer 2016 and 2017. The data revealed that peak population of jassid (16.1 jassid/3leaves) and whitefly (15.7 whitefly/3 leaves) was observed at $17^{\text {th }}$ and $16^{\text {th }}$ standard meteorological week of summer 2016, respectively. Whereas, in summer 2017 the peak population of aphid (17.8 aphid/3 leaves) was observed at $16^{\text {th }}$ standard meteorological week. There was positive correlation between pest population with maximum temperature, minimum temperature, morning relative humidity and bright sunshine. Only evening relative humidity was negatively correlated.

\section{Introduction}

Okra, Abelmoschus esculentus (L.) Moench, commonly known as ladys finger is an important vegetable crop and belongs to Malvaceae family.

The crop is grown in the several states of India including Gujarat. In India, it is cultivated in the area of about 492.7 thousand hectares with the production of 5552.3 thousand tonne.

In Gujarat, it is mainly cultivated in springsummer and rainy seasons, which occupies the area of 76.02 thousand hectares with 908.6 thousand tonne annual production. In Junagadh district, it is cultivated in 0.81 thousand hectares with annual production of 1.4 thousand tonne (Anonymous, 2016). A major constraint in vegetable production is poor and inadequate control of pests and diseases, which cause high yield losses (Tindall, 1983). Many of pests occurring on cotton are found to ravage the okra crop.

Among the various pests of okra, Aphid, jassid, whitefly, shoot and fruit borer and mite are the major pests infesting okra under Junagadh conditions of Gujarat State. Among insect pests of okra, jassid, Amrasca biguttula biguttula Ishida, whitefly, Bemisia tabaci Gennadius and shoot and fruit borer, Earias vittella Fabricius are the notorious insect pests (Singh et al., 1993). 
Chaudhary and Dadheech (1989) reported 54.04 per cent losses in yield of okra due to jassid, aphid, whitefly and shoot and fruit borer in Rajasthan. The sucking pest complex consisting of aphids, leaf hoppers, whiteflies, thrips and mites are major pests and cause 17.46 per cent yield loss in okra (Sarkar et al., 1996)

Jassid, A. biguttula biguttula (Ishida) is an important sucking pest of okra that feeds mostly on lower surface of okra leaves, leading to hopper burn (Bindra and Mahal, 1979) causing considerable yield losses upto 40 to 56 per cent (Rawat and Sahu, 1973; Krishnaiah, 1980 and Hormchan et al., 2001).

Whitefly, B. tabaci has become a serious pest on vegetables, field crops and ornamental plant and fruits world-wide and attacks 176 plant species (Ren et al., 2001) with considerable damage (Oliviera et al., 2001). The pest is also known to transmit the serious disease namely yellow vein mosaic, affecting the quality of the produce.

To avoid yield losses caused by the sucking pest complex and encourage cultivation of okra crop on large area and to increase the production and productivity of okra in Gujarat as well as in India, all efforts are needed to tackle these major sucking pests by knowing their peak period of infestation through studies on seasonal abundance as well as according to mode of action of insecticides, biopesticidesand botanicals.

Seasonal abundance of the insect pest provides not only the information of initiation of the pest but also provides the peak activity of the particular pest. Biotic and abiotic parameters play a vital role in population build-up of insect pest. Correlation study helps in to provide either positive or negative association of pest population with biotic or abiotic factors. It gives direct influence of particular parameter on pest population build-up as well as its indirect effect through other parameters. In the present study the efforts have been made to study the seasonal incidence, its correlation with biotic and abiotic parameters on population build-up of major insect pest of okra.

\section{Materials and Methods}

The field experiment on seasonal incidence of pestson okraand its relation with weather parameters was carried out at Instructional Farm, College of Agriculture, JAU, Junagadh. The Okra (GJO-3) was sown in a block size of $20 \mathrm{~m} \times 20 \mathrm{~m}$ keeping the spacing of $60 \times 30$ $\mathrm{cm}$. All the recommended agronomic practices viz. weeding, harrowing, application of fertilizer dose and irrigation were carried out timely and properly to raise good crop. The crop area kept free from any insecticidal application throughout the season. The crop area was divided into ten quadrates $(1.2 \times 1.2$ $\mathrm{m}$ each).

\section{Observation recorded}

Observation on population of sucking pests was taken at the appearance of the pest on five randomly selected and tagged plants from ten different quadrates of crop area. Jassid, whitefly and aphids counts was recorded early in the morning at weekly interval on three leaves i.e. upper leaves, middle leaves and bottom leaves from each randomly selected plant. With a view to study the impact of different weather factors on pest abundance, a multiple regression of pest population with different weather parameters was worked out. The meteorological data on temperature (maximum and minimum), relative humidity (morning and evening) and mean bright sunshine hours in different standard weeks was obtained from the Meteorological Observatory, Department of Agricultural Meteorology, JAU, Junagadh. 


\section{Results and Discussion}

\section{Jassid, Amrasca biguttula biguttula (Ishida)}

A study was carried out to know the occurrence and abundance of jassid on GJO-3 variety of okra during summer 2016 and summer 2017. The data obtained are summarized in Table 1 and depicted in Figure 1 and 2.

The result presented in Table 1 and Figure 1 and 2 revealed that the population of jassid was ranging from 0.7 to 16.1 jassid per three leaves) during summer 2016. Whereas during summer 2017 it was ranging from 0.7 to 15.3 jassid per three leaves. In both the season the jassid incidence noticed from third week after germination (i.e. 11 standard meteorological week). During both the year of experiment, the population of this pest showed two peaks on okra crop. In summer 2016 first peak of jassid was observed at $17^{\text {th }}$ standard meteorological week with $16.1 \mathrm{jassid} / 3$ leaves (i.e. $9^{\text {th }} \mathrm{WAG}$ ) and second peak was observed at $19^{\text {th }}$ standard meteorological week with 15.2 jassid/3 leaves (i.e. $11^{\text {th }} \mathrm{WAG}$ ). Whereas in summer 2017 the first peak of jassid was observed at $15^{\text {th }}$ standard meteorological week with 15.3 jassid/3 leaves (i.e. $7^{\text {th }} \mathrm{WAG}$ ) and second peak was observed at $17^{\text {th }}$ standard meteorological week with 14.4 jassid/ 3 leaves (i.e. $10^{\text {th }} \mathrm{WAG}$ ). In both the years after second peak the population declined gradually during the successive weeks. However, the jassid population remained active throughout the crop period.

Anitha and Nandihalli (2008) recorded that the 4.33 jassid per 3 leaves from first week of April and peak jassid incidence (18.44 jassid per 3 leaves) was noticed during the last week of June. Kumari et al., (2009) concluded that infestation of jassid was started (3.53 jassid per leaf) at 21 days old okra crop and reached its peak (17.33 jassid per leaf) when the crop was about 63 days old and thereafter its population followed declining trend. Das et al., (2011) observed that the jassid first appeared in $3^{\text {rd }}$ WAS and maximum population reached during 5 to 7 WAS.

Study on effect of various weather parameters on the fluctuation of jassid population on okra during summer 2016 (Table 3) indicated that the pest population showed significant positive correlation with maximum temperature $(\mathrm{r}=0.545)$. While, minimum temperature $(\mathrm{r}=370)$ and morning relative humidity $(r=0.277)$ and bright sunshine $(r=$ 0.392 ) were non significantly positively correlated. Only evening relative humidity $(\mathrm{r}=-0.219)$ was negatively correlated with pest population among studied parameters. The same trend was observed in the year 2017. The highly significant correlation was observed with maximum temperature $(\mathrm{r}=$ 0.826). Minimum temperature $(\mathrm{r}=0.4378)$, morning relative humidity $(\mathrm{r}=0.147)$ and bright sunshine $(r=0.232)$ were positively correlated. Whereas, evening relative humidity was negatively correlated with the pest population.

Kumawat et al., (2000) concluded that correlation study of the jassid with abiotic factors indicated the significantly positive correlation between jassid population and maximum temperature. Mandal (2002) reported that jassid population exhibited significant positive correlation with maximum and minimum temperature. Iqbal et al., (2010) reported that the jassid population and minimum temperature had significant positive correlation and the other factors were found non-significant.

Singh et al., (2013) reported that the jassid population showed negative correlation with maximum, minimum and mean temperature and maximum and minimum relative humidity. 


\section{Whitefly, Bemisia tabaci (Gennadius)}

The result presented in Table 1 and Figure 3 and 4 revealed that the population of whitefly was ranging from 1.8 to 16.2 whitefly per three leaves during summer 2016. Whereas during summer 2017 it was ranging from 3.2 to 15.7 whitefly per three leaves per plant. In 2016 the whitefly incidence noticed from third week after germination (i.e. 11 standard meteorological week) while during 2017 it was noticed from second week after germination.

During both the year of experiment, the population of this pest showed two peaks on okra crop. In summer 2016 first peak (16.2 whitefly/3 leaves) was observed at $16^{\text {th }}$ standard meteorological week and second peak (12.8 whitefly/3 leaves) was observed at $20^{\text {th }}$ standard meteorological week. Whereas in summer 2017 the first peak (15.7 whitefly/3 leaves) of whitefly was observed at $16^{\text {th }}$ standard meteorological week and second peak 13.2 whitefly/ 3 leaves) was observed at $20^{\mathrm{h}}$ standard meteorological week. In both the years after second peak the population declined gradually during the successive weeks. However, the whitefly population remained throughout the crop period.

Solanki (2005) found that the incidence of whitefly initiated from the $4^{\text {th }}$ week after sowing and highest population peak (10.45 whitefly per leaf) was observed after the $10^{\text {th }}$ week of sowing. Dabhi (2007) revealed that the incidence of whitefly was noticed during $9^{\text {th }}$ to $11^{\text {th }}$ week after sowing during summer. Anitha and Nandihalli (2008) recorded that 9.16 whitefly per 3 leaves, from first week of April. Peak whitefly incidence was noticed during last week of April (14.91 whitefly per 3 leaves). Sahito et al., (2012) recorded whitefly population $(5.00 \pm 0.75$ per leaf). First record $(6.04 \pm 0.62$ whitefly per leaf $)$ in $4^{\text {th }}$ week of March and $2^{\text {nd }}$ peak $(7.72 \pm 1.08$ per leaf $)$ in $3^{\text {rd }}$ week of April. Pal et al., (2013) recorded that the incidence of whitefly started in the $2^{\text {nd }}$ week of April. The population of the whitefly increased sharply and reached at peak within a month of its appearance in the field.

Study on effect of various weather parameters on the fluctuation of whitefly population on okra during summer 2016 (Table 3) indicated that the significant positive correlation between pest population and maximum temperature $(\mathrm{r}=0.523)$ while minimum temperature $(\mathrm{r}=252)$ and morning relative humidity $(\mathrm{r}=0.025)$ and bright sunshine $(\mathrm{r}=$ 0.451 ) were positively correlated.

Only evening relative humidity ( $\mathrm{r}=-0.378)$ was negatively correlated with pest population among studied parameters. The same trend was observed in year 2017, highly significant correlation observed with maximum temperature $(r=0.708)$. Minimum temperature $(\mathrm{r}=0.255)$, morning relative humidity $(\mathrm{r}=$ $0.025)$ and bright sunshine $(r=0.431)$ were positively correlated. Whereas, evening relative humidity $(\mathrm{r}=-0.082)$ was negatively correlated with the pest population.

Kumawat et al., (2000) showed that the maximum temperature was significantly positively correlated with whitefly density. Pun et al., (2005) revealed that there was positive correlation between whitefly population and maximum and minimum temperature and sunshine hours, whereas morning relative humidity, wind velocity and total rainfall had negative correlation on whitefly population. Solanki (2005) found that whitefly population had significant positive correlation with maximum temperature and significant negative correlation with minimum temperature as well as morning relative humidity. Dabhi (2007) revealed that the physical factors bright sunshine hours and temperature (maximum and minimum) showed negative effect during summer. 
Table.1 Seasonal incidence of sucking pests on okra during years 2016 and 2017

\begin{tabular}{|c|c|c|c|c|c|c|c|}
\hline WAG & $\begin{array}{c}\text { Std. Met. } \\
\text { week }\end{array}$ & \multicolumn{2}{|c|}{ Number of jassid/3 leaves } & \multicolumn{2}{|c|}{ Number of whitefly/3 leaves } & \multicolumn{2}{|c|}{ Number of aphid/3 leaves } \\
\hline $\mathbf{1}$ & $\mathbf{2 0 1 6}$ & $\mathbf{2 0 1 7}$ & $\mathbf{2 0 1 6}$ & $\mathbf{2 0 1 7}$ & $\mathbf{2 0 1 6}$ & $\mathbf{2 0 1 7}$ \\
\hline $\mathbf{2}$ & $\mathbf{1 0}$ & 0.0 & 0.0 & 0.0 & 0.0 & 0.0 & 0.0 \\
\hline $\mathbf{3}$ & $\mathbf{1 1}$ & 0.0 & 0.0 & 0.0 & 3.2 & 1.6 & 1.3 \\
\hline $\mathbf{4}$ & $\mathbf{1 2}$ & 1.7 & 0.7 & 3.9 & 5.1 & 2.3 & 2.7 \\
\hline $\mathbf{5}$ & $\mathbf{1 3}$ & 4.7 & 2.1 & 5.2 & 6.2 & 6.2 & 6.8 \\
\hline $\mathbf{6}$ & $\mathbf{1 4}$ & 9.3 & 9.4 & 9.8 & 10.3 & 8.4 & 10.4 \\
\hline $\mathbf{7}$ & $\mathbf{1 5}$ & 13.2 & 15.3 & 10.7 & 11.4 & 10.2 & 13.7 \\
\hline $\mathbf{8}$ & $\mathbf{1 6}$ & 15.4 & 11.2 & 16.4 & 13.3 & 11.3 & 15.3 \\
\hline $\mathbf{9}$ & $\mathbf{1 7}$ & 16.1 & 9.2 & 13.8 & 14.7 & 13.7 & 17.8 \\
\hline $\mathbf{1 0}$ & $\mathbf{1 8}$ & 14.3 & 14.4 & 11.2 & 12.3 & 14.1 & 14.1 \\
\hline $\mathbf{1 1}$ & $\mathbf{1 9}$ & 15.2 & 11.7 & 8.3 & 11.8 & 9.3 & 11.9 \\
\hline $\mathbf{1 2}$ & $\mathbf{2 0}$ & 12.8 & 9.7 & 12.8 & 13.2 & 5.8 & 6.4 \\
\hline $\mathbf{1 3}$ & $\mathbf{2 1}$ & 9.7 & 7.2 & 8.3 & 10.3 & 5.1 & 5.3 \\
\hline $\mathbf{1 4}$ & $\mathbf{2 2}$ & 6.2 & 7.2 & 5.1 & 7.2 & 3.8 & 4.7 \\
\hline $\mathbf{1 5}$ & $\mathbf{2 3}$ & 3.4 & 5.3 & 3.7 & 4.3 & 2.9 & 3.2 \\
\hline $\mathbf{1 6}$ & $\mathbf{2 4}$ & 1.9 & 3.1 & 1.8 & 3.2 & 1.3 & 1.7 \\
\hline
\end{tabular}

Table.2 Correlations of weather parameters with pest complex of Okra during year 2017 and 2017

\begin{tabular}{|c|c|c|c|c|c|c|}
\hline \multirow[t]{2}{*}{ Parameter } & \multirow[t]{2}{*}{ Year } & \multicolumn{2}{|c|}{ Temp. } & \multicolumn{2}{|c|}{ R.H. } & \multirow[t]{2}{*}{ BSS } \\
\hline & & Max. & Min. & Morn. & Even. & \\
\hline \multirow[t]{2}{*}{ Jassid } & 2016 & $0.5454 *$ & 0.3700 & 0.2774 & -0.2119 & 0.3929 \\
\hline & 2017 & $0.8265^{* *}$ & 0.4378 & 0.1477 & -0.0459 & 0.2323 \\
\hline \multirow[t]{2}{*}{ Whitefly } & 2016 & $0.5238^{*}$ & 0.2521 & 0.0254 & -0.3781 & 0.4510 \\
\hline & 2017 & $0.7087 * *$ & 0.2553 & 0.2284 & -0.0827 & 0.4316 \\
\hline \multirow[t]{2}{*}{ Aphid } & 2016 & 0.3436 & 0.0581 & -0.0269 & -0.4755 & $0.5531^{*}$ \\
\hline & 2017 & $0.6105^{*}$ & 0.1011 & 0.0613 & -0.2336 & 0.4259 \\
\hline
\end{tabular}

Singh et al., (2013) reported that the whitefly population showed negative correlation with maximum, minimum and mean temperature and maximum and minimum relative humidity showed positive correlation.

\section{Aphid, Aphis gossypii (Glover)}

The result presented in Table 1and Figure 5 and 6 revealed that the population of aphid was ranging from 1.3 to 14.1 aphid per three leaves during summer 2016. Whereas during summer 2017 it was ranging from 1.3 to 17.8 whitefly per three leaves per plant. In both the year the aphid incidence noticed from second week after germination (i.e. $10^{\text {th }}$ standard meteorological week). During both the years of experimentation, the population of this pest showed only one peak on okra crop. In summer 2016 peak population (14.1 aphid/3 
leaves) was observed at $17^{\text {th }}$ standard meteorological week (i.e. $9^{\text {th }}$ WAG). Whereas, in summer 2017 the peak population of aphid (17.8 aphid/3 leaves) was observed at $16^{\text {th }}$ standard meteorological week (i.e. $8^{\text {th }} \mathrm{WAG}$ ). In both the years after peak level the population declined gradually during the successive weeks. However, the aphid population was appeared during the crop growth throughout the crop period.

Earlier, Saha (2015) reported that, the incidence was highest in the second week of February with 15.29 aphids/3 leaves. Thereafter gradual decrease was observed in the population up to the last week of April and reached to the lowest (6.52 aphids/3 leaves) due to hot weather. In the month of May the population again started increased up to the end of the season (10.64 aphids/3 leaves)

Study on effect of various weather parameters on the fluctuation of aphid population on okra during summer 2016 (Table 3) indicated that the positive correlation between pest population and maximum temperature $(\mathrm{r}=0.343)$, minimum temperature $(\mathrm{r}=0.058)$ and significantly positive correlation with bright sunshine $(\mathrm{r}=0.451)$. Whereas, morning relative humidity ( $\mathrm{r}=-0.026)$ and evening relative humidity $(r=-0.475)$ were negatively correlated with pest population among studied parameters. The slightly different trend was observed in year 2017, significant positive correlation observed with maximum temperature $\quad(\mathrm{r}=\quad 0.610) . \quad$ Minimum temperature $(\mathrm{r}=0.101)$, morning relative humidity $(\mathrm{r}=0.061)$ and bright sunshine $(\mathrm{r}=$ $0.425)$ were positively correlated. Whereas, evening relative humidity $(r=-0.233)$ was negatively correlated with the pest population.

Shukla (2014) revealed that the aphid population was reached to its peak level (27.17 aphids / 3 leaves) during 14th weeks after sowing (first week of July). Whereas, the correlation study showed that aphid population had positive correlation with rainfall $(r=0.261)$ and negative correlation with both maximum and minimum temperature.

From the overall results of the present investigation it can be concluded that, first peak of jassid was observed at $17^{\text {th }}$ standard meteorological week with $16.1 \mathrm{jassid} / 3$ leaves (i.e. $9^{\text {th }}$ WAG). In case of whitefly in summer 2016 first peak (16.2 whitefly/3 leaves) was observed at $16^{\text {th }}$ standard meteorological week. Whereas, in summer 2017 the peak population of aphid (17.8 aphid/3 leaves) was observed at $16^{\text {th }}$ standard meteorological week (i.e. $\left.8^{\text {th }} \mathrm{WAG}\right)$. There was positive correlation between pest population with maximum temperature, minimum temperature, morning relative humidity and bright sunshine.

Research category: Entomology

\section{Acknowledgement}

Author thankful to College of Agriculture, Junagadh Agricultural University, Junagadh, 362001, India.

Research Guide or Chairperson of Research: Dr. V. R. Virani.

\section{References}

Anitha, K. R. and Nandihalli, B. S. (2008). Seasonal incidence of sucking pests in okra ecosystem. Karnataka Journal of Agricultural Sciences, 21(1): 137-138.

Anonymous (2016). Indian Horticulture Database, 154-161 pp.

Baloch, A. F., Qayyum, S. M. and Baloch, M. A. (1990). Growth and yield performance of okra (Abelmoschus esculentus L) cultivars. Gomal 
University Journal of Research, 10: 191.

Bindra, O. S. and Mahal, M. S. (1979). Investigation on varietal resistance in okra, Abelmoschus esculentus (L) Moench to jassid, Amrasca biguttula biguttula. Indian Journal of Horticulture, 36: 212-219.

Chaudhary, H. R. and Dadheech, L. N. (1989). Incidence of insects attacking okra and the avoidable losses by them. Annals of Arid Zone, 28: 305-307.

Dabhi, M. V. (2007). Succession population dynamics and management of major insect pests of okra. M. Sc. (Agri) thesis submitted to Anand Agricultural University, Anand.

Das, S., Pandey, V., Patel, H. I. and Patel, K. I. (2011). Effect of weather parameters on pest disease of okra during summer season in middle Gujarat. Journal of Agrometeorology, 13(1): 38-42.

Hormchan, P., Wongpiyasatid, A. and Piyapuntawanon, S. (2001). Observation of gamma irradiated cotton populations on trend of cotton leafhopper resistance using hopperburn index. Kasetsart Journal of Natural Science, 35: 386-391.

Iqbal, J., Ashfaq, M., Hasan, M., Sagheer, M. and Nadeem M. (2010). Influence of abiotic factors on population fluctuation of leaf Hopper, Amrasca biguttula biguttula (Ishida) on okra. Pakistan Journal of Zoology, 42(5): 615-621.

Krishnaiah, K. (1980). Methodology for assessing crop losses due to pests of vegetables. In: Assessment of crop losses due to pests and diseases, Eds., $44 \mathrm{pp}$.

Krishnamurthy, K. H. (1994). Okra in Vegetables Health Series, Traditional Family Medicine, Published by Books for All, Ashok Vihar, Delhi, 12-15 pp

Kumari, K., Nath, P. and Rai, A. B. (2009). Population dynamics and economic threshold level of Amrasca biguttula biguttula ishida in okra. Vegetable Science, 36(1): 43-46.

Kumawat, R. L; Pareek, B. L. and Meena, B. L. (2000). Seasonal incidence of jassid and whitefly on okra and their correlation with abiotic factors. Annals of Biology, 16(2): 167-169.

Mandal, S. K. (2002). Management of key insect pests in summer sown okra, Abelmoschus esculentus L. Moench. $\mathrm{Ph} . \mathrm{D}$. Thesis, submitted to Rajendra Agricultural University, Samastipur.

Oliveira, M. R. V., Henneberry, T. J. and Anderson, P. (2001). History, current status and collaborative research projects for Bemisia tabaci. Crop Protection, 20: 709-723.

Pal, S., Maji, T. B. and Mondal, P. (2013). Incidence of insect pest on okra, Abelmoschus esculentus (L) Moench in red lateritic zone of West Bengal. The Journal of Plant Protection Sciences, 5(1): 59-64.

Pun, K. B., Sabitha, D. and Balasubramanian, G. (2005). Prediction of whitefly population and okra yellow vein mosaic virus disease incidence in okra. Indian Journal Virology, 16(1/2): 19-23.

Rawat, R. R. and Sahu, H. R. (1973). Estimation of losses in growth and yield of okra due to Empoasca devastans Dist and Earias spp. Indian Journal of Entomology, 35: 252-254.

Ren, S. X., Wang, Z. Z., Qui, B. L. and Xiao, Y. (2001). The pest status of Bemisia tabaci in China and non-chemical control strategies. Entomology Sinica, 8: 279-288.

Saha, R. (2015). Seasonal incidence and management of sucking pests of okra. M. Sc. Agri. thesis submitted to Mahatma Phule Krishi Vidyapeeth, Rahuri. Pp.64.

Sahito, H. A., Abro, G. H., Memon, S. A., Mal, B. and Mahmood, R. (2012). 
Influence of abiotic factors on population development of Bemisia tabaci infesting Abelmoschus esculentus. International Research Journal of Plant Science, 3(2): 012-018.

Sarkar, P. K., Mukherjee, A. B. and Ghosh, J. (1996). Assessment of loss of bhendi against red spider mite. Environmental Ecology, 14: 480-481.

Senapathi and Khan (1978). Seasonal incidence of sucking pests in okra ecosystem. Karnataka Journal Agricultural Science, 21(1): 137-138.

Shukla, N. (2014) Seasonal Incidence and Relation to Weather Parameters of Aphid and their Natural Enemies on Okra. International Journal of Scientific and Research Publications, 4(3): 11-13.

Singh, J., Sohi, A. S., Dhaliwal, Z. S. and Mann, H. S. (1993). Comparative incidence of Helicoverpa armigera $\mathrm{Hb}$. and other pests on okra and sunflower intercrops in cotton under Punjab conditions. Journal of Insect Science, 6: 137-138.

Singh, Y., Jha, A., Verma, S., Mishra, V. K. and Singh, S. S. (2013). Population dynamics of sucking insect pests and its natural enemies on okra agro-ecosystem in Chitrakoot region. African Journal of Agricultural Research, 8(28): 38143819.

Solanki, B. K. and Lohar, M. K. (2005). Effect of some insecticides on the population of insect pests and predators on okra. Asian Journal of Plant Sciences, 6(6): 920-926.

Tindall, H. (1983). Vegetables in the Tropics. Oxford Press, London, 90: 145.

\section{How to cite this article:}

Dhandge, S.R., S.A. Bangale, A.S. Vaja and Virani, V.R. 2018. Seasonal Incidence of Sucking Pest of Okra and its Relationship with Weather Parameters in Summer Season. Int.J.Curr.Microbiol.App.Sci. 7(11): 2697-2704. doi: https://doi.org/10.20546/ijcmas.2018.711.308 